\title{
Landslide susceptibility assessment using the maximum entropy model in a sector of the Cluj-Napoca Municipality, Romania
}

\author{
Anna-Hajnalka KEREKES ${ }^{1 *}$, Szilárd Lehel POSZET ${ }^{2}$, Andrea GÁL ${ }^{3}$ \\ ${ }^{1}$ Department of Technical Geography, Babeș-Bolyai University, Cluj-Napoca, Romania \\ ${ }^{2}$ Department of Environmental Sciences, Sapienta Hungarian University of Transylvania, Cluj-Napoca, \\ Romania \\ ${ }^{3}$ Department of Geography, Babeș-Bolyai University, Cluj-Napoca, Romania
}

Received 12 September 2018; Revised 12 October 2018; Accepted 13 December 2018

*Correspondence to: Szilárd POSZET, e-mail: poszet@yahoo.com

\begin{abstract}
The administrative territory of Cluj-Napoca, due to its specific geological and geomorphological characteristics and anthropic activities, has been affected for a long time by landslides. Thus, it becomes necessary to analyse affected areas with different spatial methods, with the aim of generating landslide susceptibility maps. In this research, we studied the most prone area of the city, the Becas stream watershed, situated in the Southern part of the municipality. The aim of this paper is to generate a valid susceptibility map, to be able to raise awareness about the existing situation: due to human induced activities and rapid urban growth, the peripheral part of ClujNapoca becomes more and more prone to mass-movements. We used the maximum entropy (MaxEnt) model, which was fed with accurate information on the existing landslides and seven landslide-causing factors: slope, aspect, land-use, depth of fragmentation, geology and plan- and profile curvature. The results confirm that the most influential factors are the land use and slope-angle, affected in a large degree by human activities. The accuracy of the generated map was verified using the AUC method, proving a very good performance (0.844) of the applied model.
\end{abstract}

KEYWORDS

Landslide susceptibility analysis; spatial analysis; Maximum Entropy (MaxEnt); Cluj-Napoca Municipality; GIS 


\section{Introduction}

Mass movements are a common danger; they describe the movement of rock, debris, soil, or earth material by gravity (Davis and Blesius, 2015). According to Varnes (1978), a multitude of mass movement types can be distinguished. He defines landslides as a special type of mass movement; their size can vary (smaller ones are more common) and are triggered when a threshold of stability is exceeded (earthquakes, excess of water, hydrologic inputs; Schumm, 1979; Uchida et al., 2001; Montgomery, 1994).

Landslides are amongst the most significant and dangerous geological hazards, inducing economic damage and loss, affecting the infrastructure and cities (Park, 2015; Kornejady et al., 2017).

In Romania, landslides are the most common hazards; they manifest in vulnerable areas with important human activities, like road constructions, deforestation, mining, land use change, inducing many negative effects, favoured by the absence of hazard mitigation or land planning strategies. (Kerekes et al., 2016; Necula and Niculiță, 2017). Landslides have been analysed for many years in a classical manner by Romanian researchers: Tufescu (1966), Băcăuanu (1980), Surdeanu (1988), Manea and Surdeanu (2012).

In the past decades, the interest in landslide susceptibility mapping has increased, caused by two reasons: the growing pressure of urban development and the increasing awareness of the socioeconomic significance of landslides (Aleotti and Chowdhury, 1999). In order to prevent future mass movements and to generate relevant land use strategies, it becomes necessary to analyse the affected territory with different methods. After analysing the area and identifying the landslide causing factors (both natural and anthropic), a landslide susceptibility map can be generated using spatial statistics, to provide information on the expected trends in landslide occurrence in the affected area.

In the recent decades, many studies were carried out to generate relevant landslide susceptibility maps. These studies can be divided in three main categories: heuristic, statistical, probabilistic and deterministic models (Pradhan et al., 2010; Kavzoglu et al., 2015). Several studies exist which compare and discuss the advantages and drawbacks of different methods, proving that the decision on the most relevant model to generate susceptibility maps is not a straightforward one (e.g. Guzzetti et al., 1999; Yilmaz, 2009; Felicísimo et al., 2013; Chen et al., 2016). Moreover, the selected method is suitable for cases which have specific environmental characteristics; therefore the same methodology can't be applied with the same reliability on other regions (Van Den Eeckhaut et al., 2009). In order to obtain more accurate information, it is necessary to combine two or more methods (Rossi et al., 2009).

According to Davis and Blesius (2015), heuristic methods are considered as being the basic models, especially appropriate for coarse scales; they can be easily implemented in GIS environment and are used for multi-criteria analysis or physical modelling, e.g. Blesius and Weirich, 2010, Kavzoglu et al., 2014.

Many statistic-probabilistic models were applied for landslide susceptibility, such as logistic regression, frequency ratio models, weight of evidence, random forest and maximum entropy, e.g. Luzi and Pergalani, 1999; Dahal et al., 2008; Pradhan and Youssef, 2009; Meinhardt et al., 2015; Pandey, 2015; Trigila et al., 2015; Ding et al., 2016.

Deterministic models, artificial neural network or fuzzy logic were adopted in the recent years with a great success (Neaupane and Achet, 2002; Yilmaz, 2009; Nefeslioglu et al., 2008; Kumar and Anbalagan, 2015a).

Few studies applied the maximum entropy model. This model is a statistical-probabilistic machine learning method (Kornejady et al., 2017) which was mostly applied, for species distribution, and was introduced by Phillips et al., 2004. The MaxEnt model is a Bayesian approach which focuses on maximizing probabilities, and it calculates the least biased estimates of the statistical probability, based on the input environmental factors (Phillips et al., 2006).

In this work, we used the maximum entropy model, taking into account seven landslide causing factors. The study area is represented by the South- 
ern part of the city of Cluj-Napoca, considered as having the highest predisposition to landslides.

This study area was chosen for investigation due to its specific characteristics: the area is positioned at the periphery of the city and it is the most dynamic territory from the point of view of constructions, a fact determined by the rapid population growth. Rapid population growth generates an increase in needs, which is reflected in the number of new buildings. These districts are the most predisposed to landslides, but the anthropic factors have worsened the situation.
Among the urbanistic plans of the city of ClujNapoca, an official landslide susceptibility map was found (Fig.1). We have used the existing official map to confront it with our results obtained within this research. Unfortunately, comparing these two data, we could conclude the fact that, in the case of ClujNapoca, it becomes urgent to build a new landslide susceptibility map, because the existing data is not accurate and it is overdue. Therefore, the main aim of this study is to prepare an accurate and valid susceptibility map which can be useful for hazard mitigation and land-use/land planning strategies.

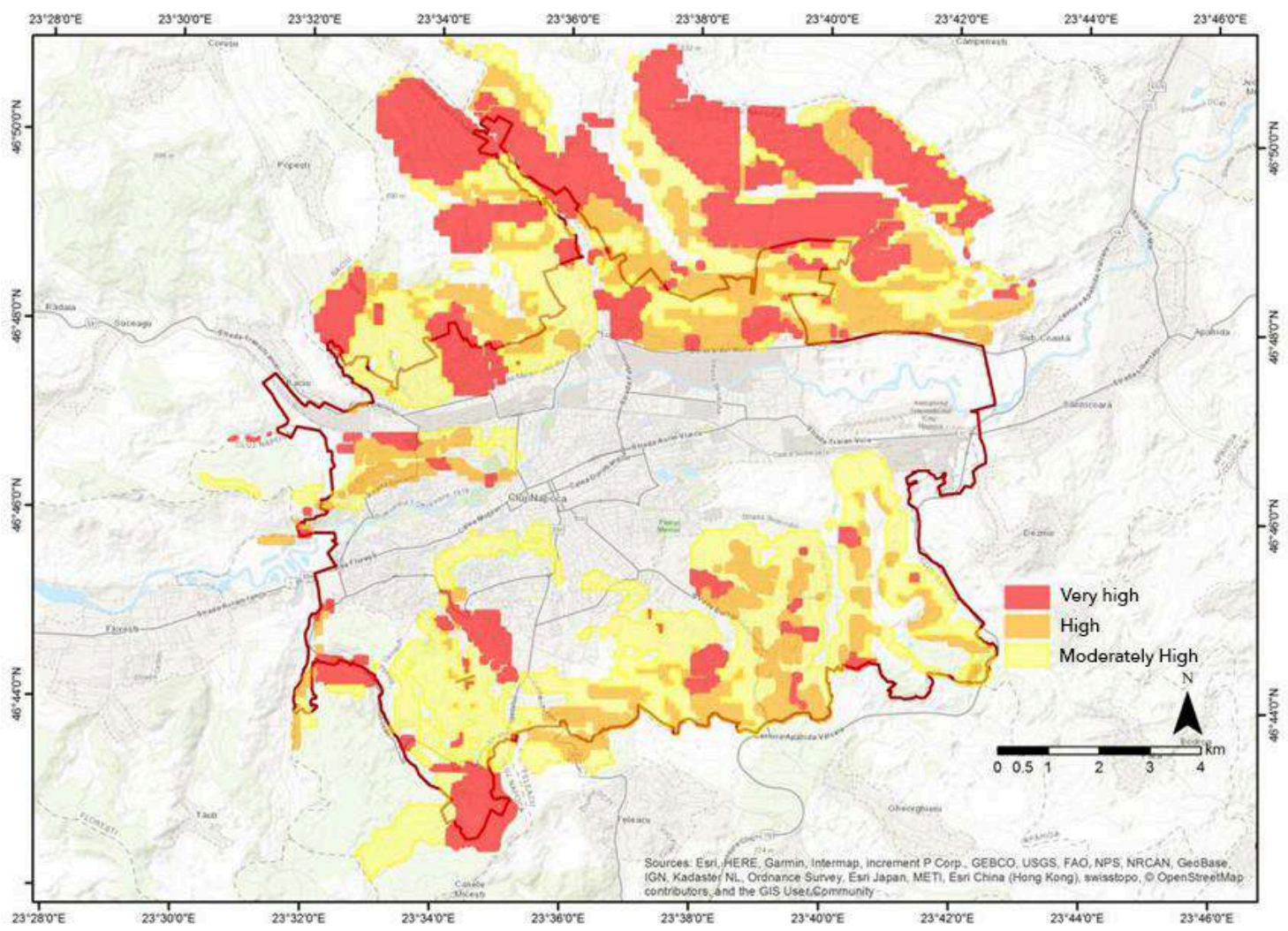

Figure 1 The official landslide susceptibility map (source: www.primariaclujnapoca.ro/proiectpug.html)

\section{Study Area}

The city of Cluj-Napoca is situated right at the connection spot between the Apuseni Mountains and the Transylvanian Plateau, at the confluence between the Someșul Mic and the Nadăș Rivers; it marks as a hilly region, thus representing a transition from the Gilău Mountains to the Someșan Plateau and the Transylvanian Plain.
Analysing the city map of Cluj-Napoca, it can be observed that many constructions, which were built until the $X X^{\text {th }}$ century, are based on the stable floodplain of the Somes River. Due to the rapid growth of the population, the districts of the city expanded rapidly towards the steeper slopes, favoured by the improvements in technology. This expansion trend contributes to increasing the land- 
slide potential in these districts. The same process appears in the watershed of the Becas stream.

The area under investigation is situated in the Southern part of the city of Cluj-Napoca, occupying a small part of the valley of the Somesul Mic River, situated on the Northern side of the Feleac Hills and was previously studied by Poszet, 2017 (Fig. 2). This territory $\left(\sim 25 \mathrm{~km}^{2}\right)$ represents the watershed of the Becaș stream and it is the most exposed territory to landslides due to high anthropic pressure.

From a geological point of view, within the study area, numerous formations can be found, such as Paleogene (Upper Eocen and Early Oligocen), Neogene (Middle Miocene) and Upper Pleisto-

Within the study area, the following formations cene formations, which are interleaved and form a complex geology; the surface of the entire area (including the terraces) is covered with slope deposits of varying thickness (Wanek and Poszet, 2011) (Fig.3).

The Western part of the study area is characterized by monocline structures and the Eastern part consists in diaper foldings.

In the Southern part of the area under investigation, Badenian formations appear under the Sarmatian ones and under a superficial layer of deposits and terraces. The youngest Quaternary deposits (Pleistocene and Holocene) create periglacial formations.

sion of sand, sandy-clay and sandstone; Dej Tuff

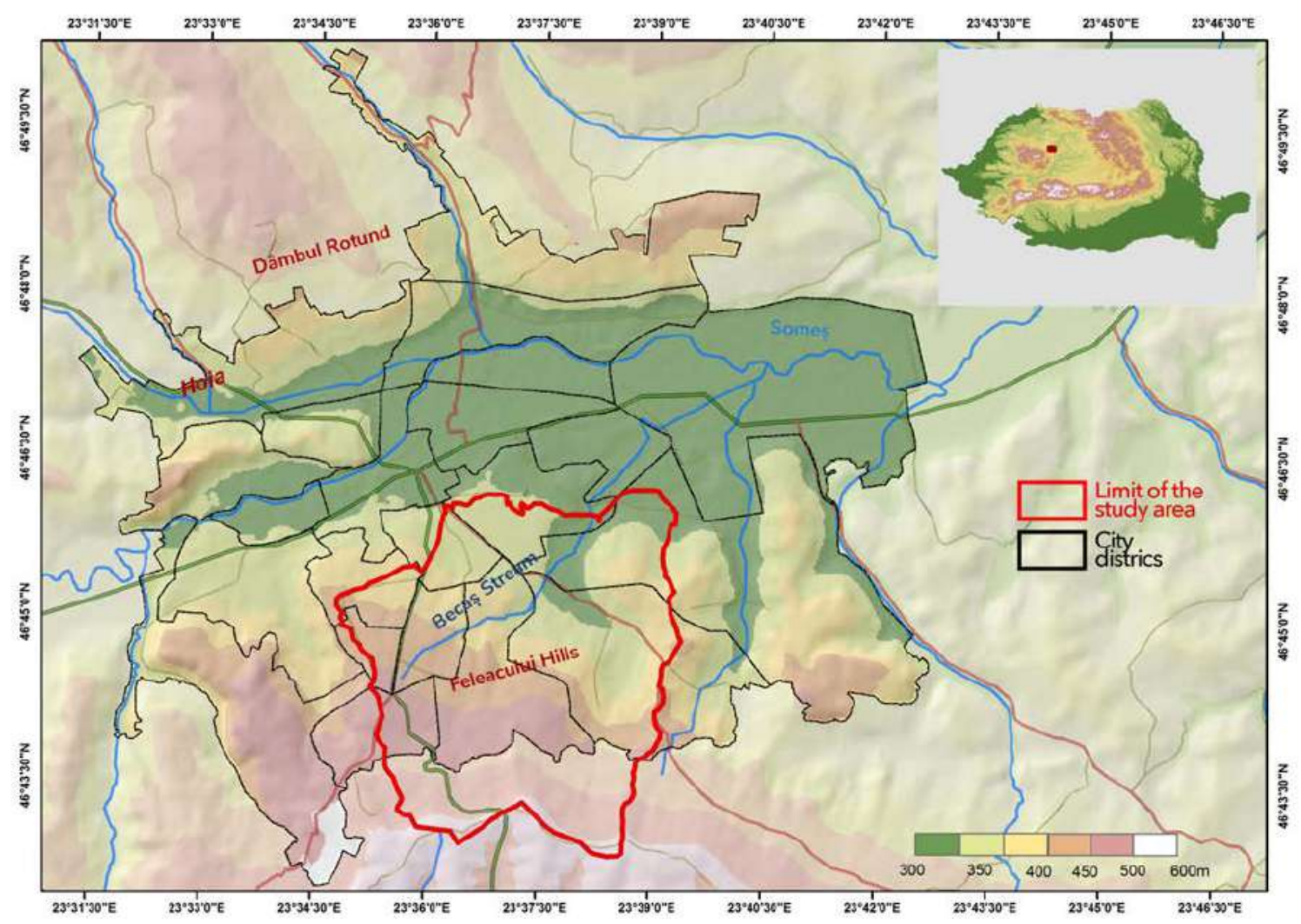

Figure 2 Geographical position of the study area within the Cluj-Napoca municipality

can be distinguished (Poszet, 2017, Fig. 3): Valea Nadăș Formation - (from the Upper Eocen) has a thickness of approximately $60-80 \mathrm{~m}$ and it consists in red clay, silt and sand. These characteristics induce the occurrence of landslides; Gruia Sandstone Formation - (from the Early Oligocen) has a thickness of $20-25 \mathrm{~m}$ and it is characterized by a succes-
Formation (from the Badenian) - has two levels of depth; the primary level contains marl and clay with a thickness of $20 \mathrm{~m}$ on which the second level was deposited (this contains tuff), with a thickness of 60 $\mathrm{m}$. This formation is stable in terms of landslides; Iris Formation (from the Lower Sarmatian) - has various clasts deposits and interleaved tuff and sand. This 
formation appears above the Badenian formations until the upper third of the northern slope of the Feleac Hills; Feleac Sandstone Formation - (from the Upper Sarmatian) Iris Formation was deposited on top of it; there is a juxtaposition of sand, sandstone and clay. These Sarmatian formations are very susceptible for landslides. In the Quaternary (the Holocene), the seven levels of the Someș River terraces took shape; these are stable in terms of landslides.
The morphostructure, morphometry and topography of the area under investigation are predisposing factors to landslide reactivation. Translational slides (type 12 according to Hungr et al., 2014) appear on the steep slopes of the southern part of the study area (>200); on the crowns and main scarps of the Pleistocene slidings rotational landslides can be observed (type 11).

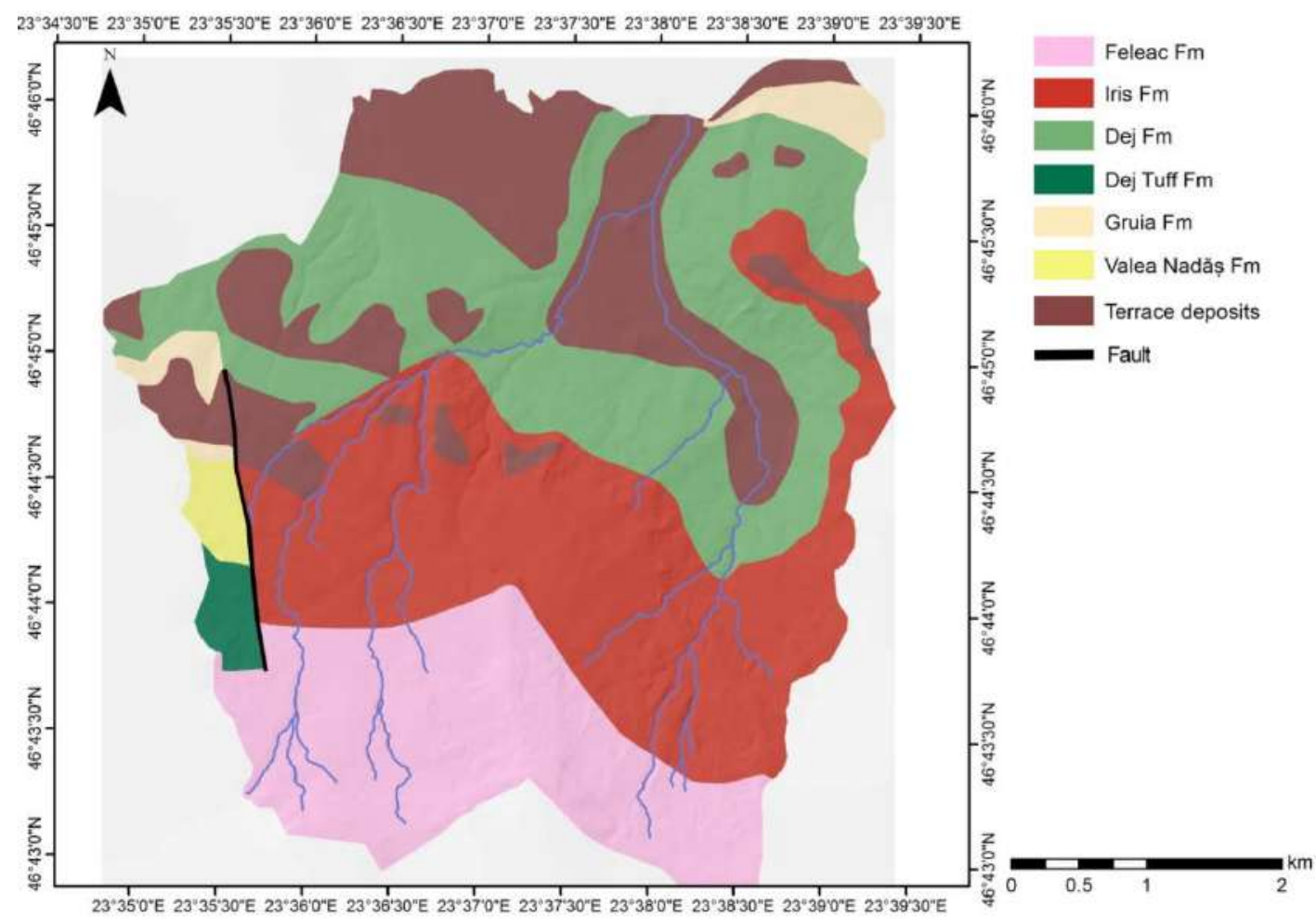

Figure 3 Distribution of the geological formations in the study area

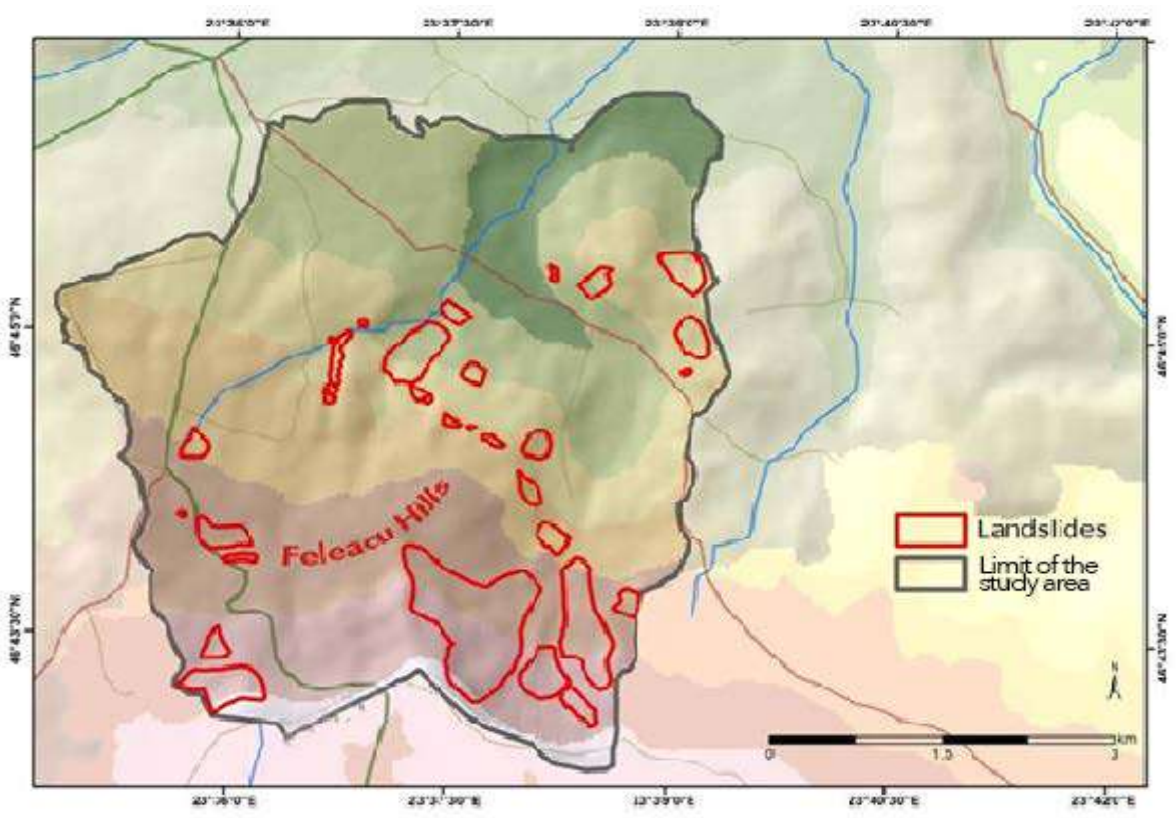

Figure 4 The distribution of the inventoried landslides in the study 
The morphology has a high complexity and it is determined by geological, anthropic, climatic characteristics and fluvial erosion. Landslide features (crowns and main scarps) dating from the Pleistocene may be observed (Wanek and Poszet, 2011, Poszet, 2017). Over time, the mass movements were redeposited and temporary stabilized, but due to anthropic factors and failures, on top of the old Pleistocene landslides, many new slope failures have occurred or reactivated due to human presence.

The climate can be considered as a control factor in the present and the past geomorphological processes. In the Pleistocene, the major relief formations were created, on which the actual geomorphological processes were grafted (Poszet, 2017). The climate determines the rhythm, the length and the intensity of the actual geomorphological processes. The actual climate, which is dryer than in the previously mentioned periods, helped the stabilization process of mass movements, but the landslides can be easily reactivated by different factors.

The precipitation is an important landslide triggering factor, because mass movements are favorized by long-lasting rainy periods, freeze-thaw and wetting-drying processes (Conforti et al. 2011; Kerekes et al., 2016).

\section{Materials and methods}

\subsection{Materials}

In this research, we used a wide range of data: topographical maps (1:5000, 1975), geological maps (1:5000, Wanek and Poszet, 2011), aerial imagery (ANCPI - National Institute of Cadaster (2012) and Google Earth 3D (2014)) and open-source data. These data were processed in ArcGIS software. In order to obtain a precise digital elevation model (DEM), we digitized the contour lines from the topographical maps. Interpolating the resulted vector, we generated a $1 \times 1 \mathrm{~m}$ resolution DEM.

Based on the above mentioned data, we could identify and map all the landslides of the area, obtaining a landslide inventory map (Fig.4.) which was verified during field-works. The landslide inventory contains 34 landslides, with a total area of $25.8 \mathrm{~km}^{2}$, which means that approximately $10 \%$ of the territory is covered by mass-movements.

After analyzing the landslide inventory that we compiled, we selected the landslide predisposing factors to be evaluated with our approach: lithology, topographical parameters (slope aspect, slope angle, depth of fragmentation, plan- and profile curvature) and land use.

The geomorphometric parameters were derived from the $1 \times 1 \mathrm{~m}$ elevation model. To store all the information in a uniform thematic database, the pixel size for all products was set to $1 \mathrm{~m}$ :

i) Slope aspect (Fig. 5.a): the slope aspect influences landslide processes by producing major differences in climatic parameters, controlling the duration and angle of sunlight, evapotranspiration, moisture retention and vegetation cover type (Dai et al., 2001; Sidle and Ochiai; 2006; Rahmati et al., 2016; Kerekes et al., 2016);

ii) Slope angle (Fig. 5.b): in fact, this can be considered the most important causative factor, because all mass movements occur as a consequence of gravitational force (Liberatoscioli et al., 2017, Pradhan and Youssef, 2009). In our case, most of the mass movements occur near or inside the perimeter of the newly built areas, i.e. on slopes having values between 50 and 100;

iii) Profile curvature and plan curvature (Fig. 5.c and d): Profile curvature measures the rate of change of the slope; plan curvature influences the convergence or divergence of downhill flowing water. Therefore, both become important factors in landslide formation (Meinhardt et al., 2015);

iv) Depth of fragmentation (Fig. 5.e) is a wellknown geomorphological indicator; it represents the relative altitudinal difference per square kilometer. This indicator shows an outgo rate of the relief's quantitative characteristics (Tatiana Constantinov et al., 2009).

Apart from the topographical parameters, another landslide predisposing factor that was considered in the analysis is geology. The type of mass-movements under investigation mostly occurs on sedimentary rocks like clays, marls or sandy-clay. The high occurrence of landslides in the study area is explained by the presence of Oligocene, Miocene 
and Pleistocene sedimentary rocks, which cover the

a) SLOPE ASPECT

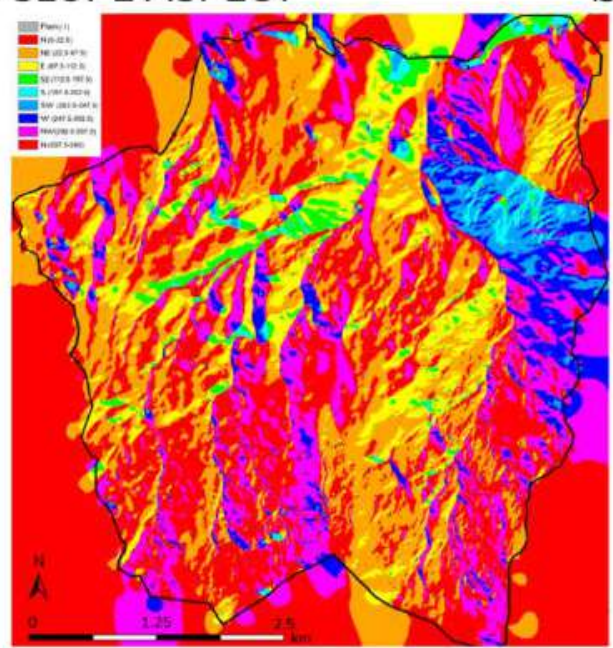

c) PLAIN CURVATURE

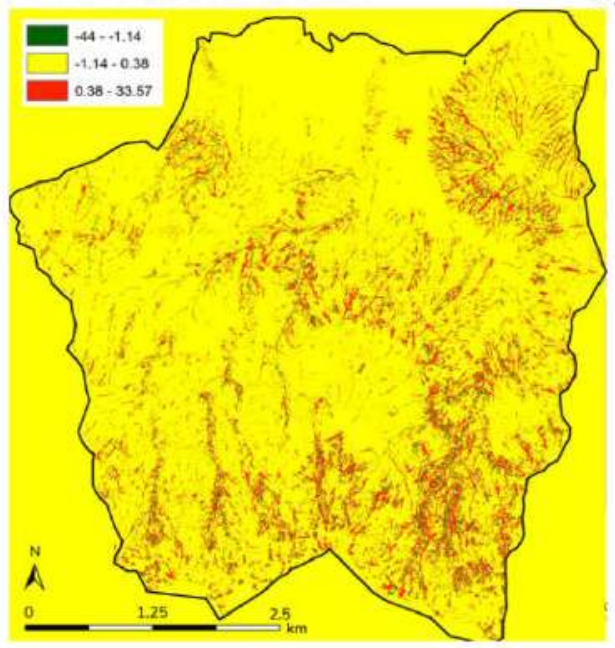

entire territory, presented in section 2 .

b) SLOPE ANGLE

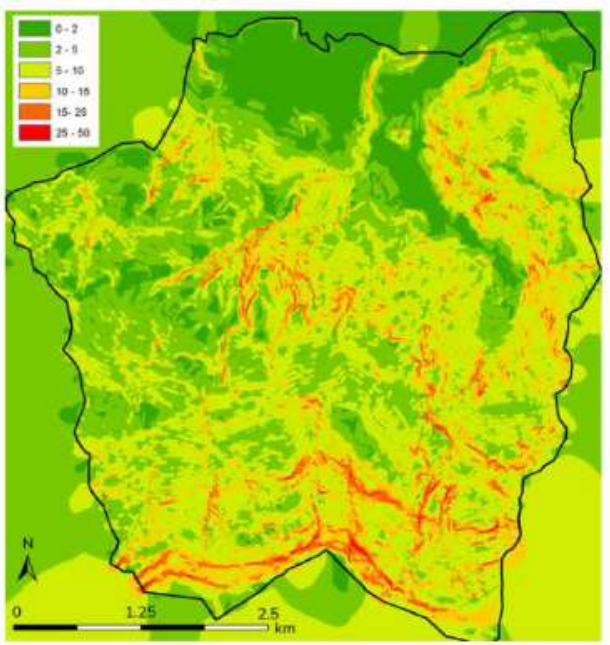

d) PROFILE CURVATURE

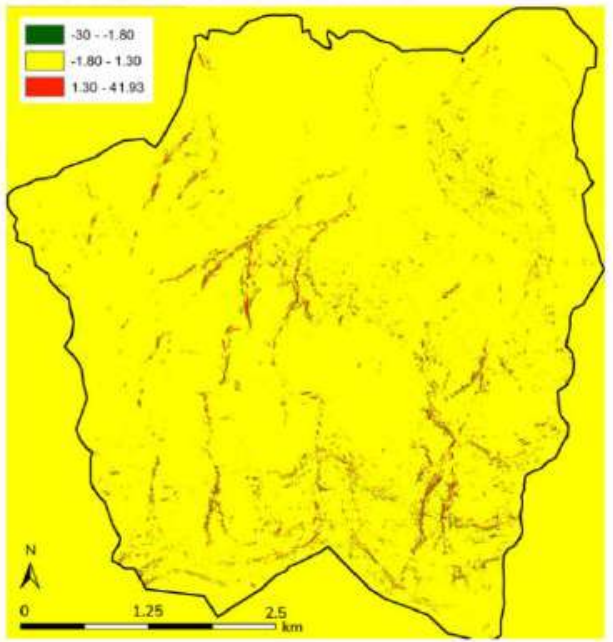

e) DEPTH OF FRAGMENTATION

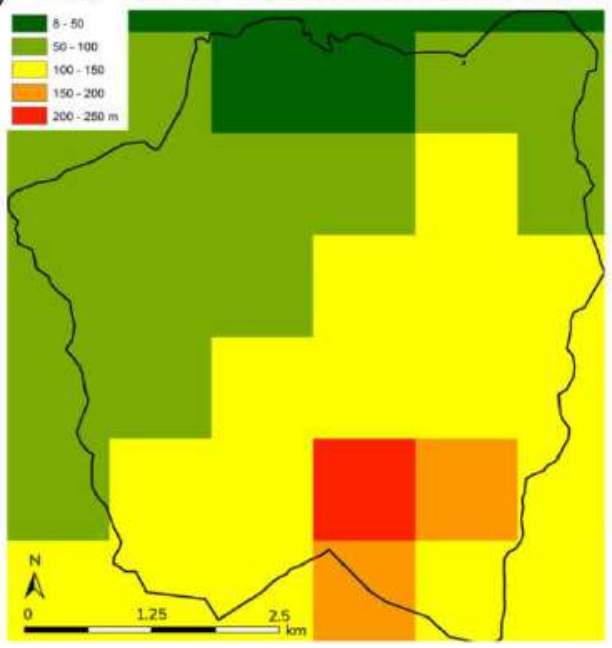

Figure 5 The morphometric parameters of the study area 
Another landslide-causing factor is land use (Fig.6.) This vector layer was obtained from the open-source Corine Land Cover 2012 database.

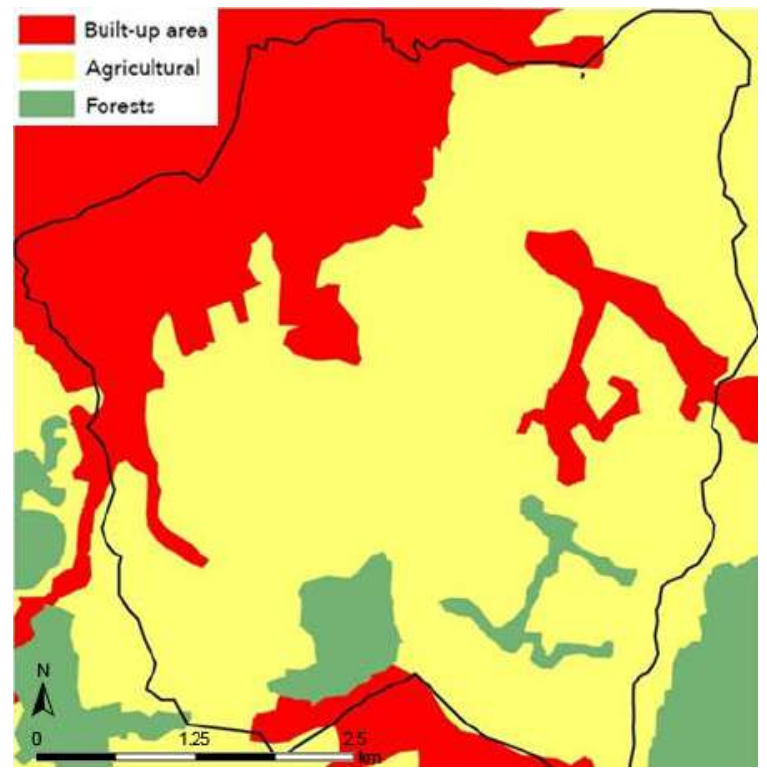

Figure 6 The land-use of the study area

\subsection{Methods}

The Maximum Entropy model is a statistical-probabilistic machine learning method, which has been applied to many different fields, such as environmental sciences for predicting species distribution, (being proposed for the first time by Phillips et al., 2004 , for the case when just presence data is available in order to calculate the best positive distribution and used with a great accomplishment by Pearson et al., 2007, Elith et al., 2011; Bajat et al., 2011; Yang et al., 2013; Muscarella et al., 2014; Cao et al., 2016), groundwater mapping (Rahmati et al., 2016; Wahyudi et al., 2012), crop planting regionalization (Franklin, 2009; Yu et al., 2014; Jaime et al., 2015).

Recently, this method was applied with a great success in landslide susceptibility mapping: Liu et al., 2012, Reza et al., 2012; Vorpahl et al; 2012; Pourghasemi et al., 2012a; Felicísimo et al.; 2013; Park, 2015; Davis and Blesius, 2015; Moosavi and Niazi, 2016; Lombardo et al., 2016; Kornejady et al., 2017. Pandey et al., 2018 investigated in India the territory along the state highway corridor Tipari to Ghuttu. This area has similar geological characteristics to our territory, characterized by complex geological formations, where clay is predominating. In this study, the Maximum Entropy principle was applied with a high performance, indicating the fact that this model is suitable for territories with a complex geology.

The MaxEnt method has a complex math, but it does not require high precision surveys (Kornejady et al., 2017). Entropy is a measurement of disorder, imbalance and uncertainty of a system (Yufeng and Fengxiang, 2009). The Boltzmann principle describes the one-to-one relationship between the quantity of entropy of a system and the degree of disorder (Yufeng and Fengxiang, 2009).

The maximum entropy model originates from information theory and statistical mechanics. Based on Boltzmann's H-theorem, Shannon (1948) managed to define entropy, as the expected value (average) of the information contained in the existing data:

$H_{(X)}=E[I(X)]=E[-\ln (-\pi(x))]$

where, $E$ is the expected value operator and $I$ is the information content.

Therefore, the expression can be defined as the negative natural logarithm of the probability distribution: the expected value of a random variable is the average of the experiment it represents (observed data) (Hamming, 1991; Ross, 2014). Jaynes (1957) determined the probability distribution generated from maximum entropy model as the least biased possible estimate on a given information, therefore, when using predictive algorithms, the most performant model should coincide with the one that has Maximum Entropy (Lombardo et al., 2016).

The MaxEnt model applied by Phillips et al., 2004, was conceived as a software by the Center for Biodiversity and Conservation at the American Museum of Natural History (AMNH) through a publicprivate partnership between the AMNH and AT\&TResearch.

The advantages of the model in prediction analyses include the following: it requires only presence data using environmental information (factors) for the whole study area; it can utilize both continuous and categorical data; the MaxEnt probability distribution is amenable to analysis; MaxEnt is a generative approach, which means that it can be used 
when we have limited amount of training data (landslides) (Phillips et al. 2004; Park, 2015).

As a prime step, the MaxEnt model calculates a uniform probability distribution function as a primary data. In this data, every single pixel is assumed to have the same probability of landslide occurrence (Kornejady et al., 2017). Following the previous step, some constraints modify this uniform probability distribution function to realize an optimal probability distribution of the phenomenon (landslides) over a spatial context (in our case: land use, geomorphological characteristics, geology) (Phillips et al., 2004; Phillips and Dudík, 2008; Kornejady et. al., 2017; Elith et al., 2011). Different features are represented by different predisposing factors, but these features represent the corresponding functions of the predisposing factors (Phillips et al., 2006; Elith et al., 2011). Therefore, we can conclude that the features, factors, and constraints are closely connected to each other (Phillips et al., 2006; Elith et al., 2011, Halvoresen, 2012).

According to Davis and Blesius, 2015, the presence-only characteristic of landslides makes the maximum entropy model, which is made for species habitat analysis, appealing; geomorphological events have many common characteristics with biological occurrences in that while they respond to environmental factors, mass movements can increase the likelihood of other events in the proximity of the affected area, due to morphological and hydrologic conditions.

A landslide represents a complex system characterized by the exchange of materials and energy with the environment, therefore, landslides can be measured using the information entropy model (Yang and Qiao, 2009). The entropy of a landslide represents the extent of the various factors which are controlling the development of a landslide (Pourghasemi et al., 2012b). The resulted entropy value can be used to calculate weights of the system (Yang et al., 2010).

In this work, the landslide susceptibility map was generated by the MaxEnt software (https://biodiversityinformatics.amnh.org/open_sour ce/maxent/ using all the prepared thematic maps mentioned above.
After generating the landslide susceptibility map, map evaluation becomes necessary. In order to evaluate our susceptibility map, it is necessary to verify the results by using different statistical methods. Model evaluation is a fundamental step in comparing the predictions with real world data-sets, in order to evaluate their performance (Beguería, 2006).

The most used method is the receiver operating characteristic curve (ROC) method. The ROC method is a threshold independent method; it plots different accuracy values realized against the whole range of possible threshold values (Beguería, 2006; Deleo, 1993).

Therefore, applying the ROC curve method, we can assess the accuracy of the MaxEnt model by comparing the obtained susceptibility map (probability map) with the landslide inventory (Chen et al., 2016; Beguería, 2006; Petrea et al., 2014; Bayes, 2015).

The ROC curve was realized using the number of correctly (true-positive) and the number of incorrectly (false-positive) classified pixels (Kavzoglu et al., 2015). The values from the OX axis represent surfaces, with no landslides, where the applied model has calculated a high probability (false positive). The values from the OY axis coincide with the surfaces with landslides, where the model has determined a high probability (true positive) (Petrea et al., 2014).

\section{Results and Discussions}

After running the MaxEnt software, the resulted values were grouped into five classes (Fig. 7A.), using the natural breaks distribution: representing very low, low, moderate, high and very high susceptibility levels. To assess the model's performance, we used the AUC (Area Under the Curve) method.

The prediction accuracy is high when the values are higher than 0.9. AUC values between 0.7 and 0.9 represent reasonable discrimination ability; furthermore, values under 0.5 indicate a poor quality of the results (Swets, 1988). With the maximum entropy model, we obtained a 0.844 AUC value (Fig. 7B), which means that our results have reasonable discrimination ability, therefore can be used for further studies. 

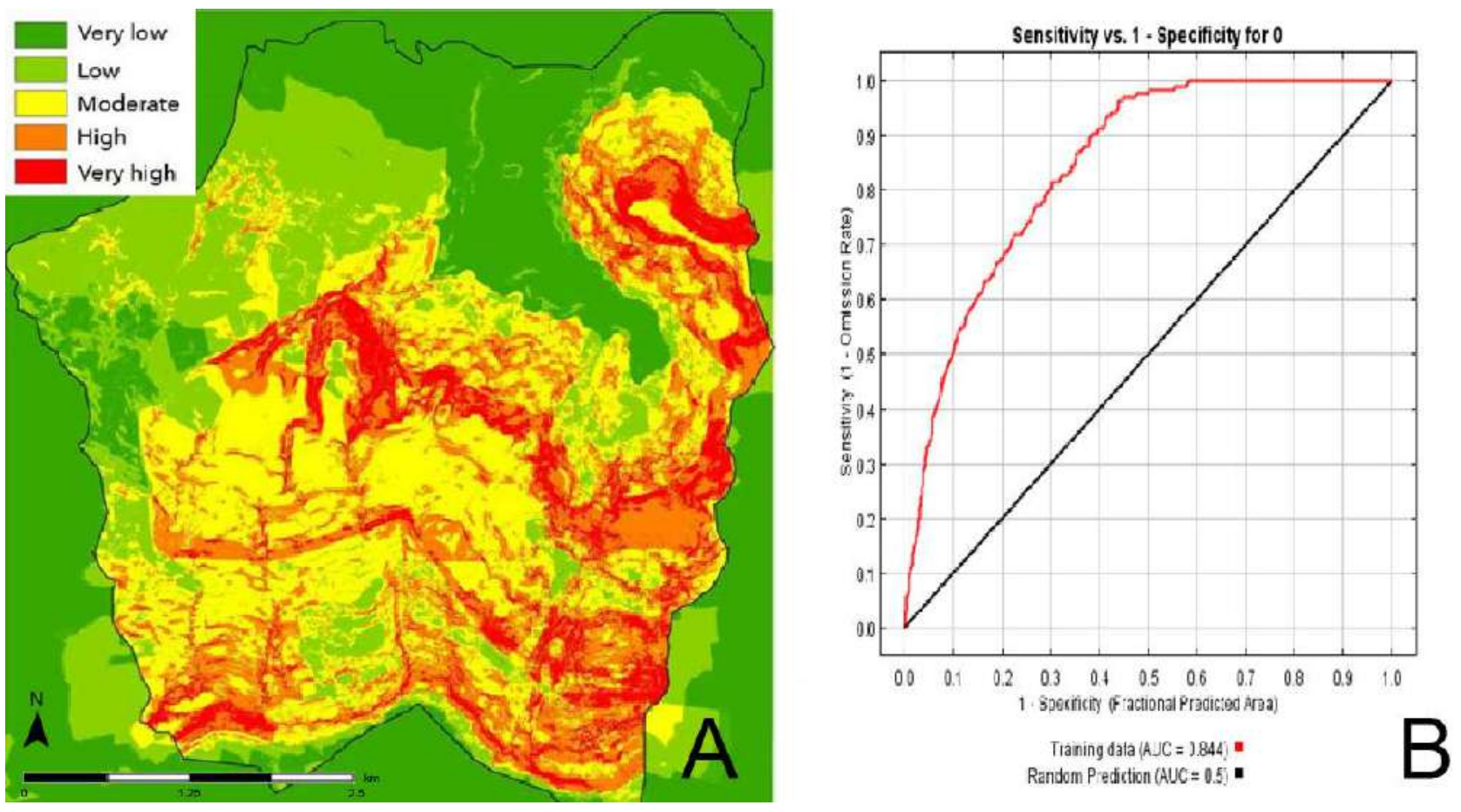

Figure 7 The resulted landslide susceptibility map for the study area (A) and the ROC curve of the susceptibility map (B)

On this map we can observe the fact that the highly prone areas outlined by the MaxEnt method are representing the Pleistocene landslides.

Analysing the resulted map (Fig. 7A), we obtained that $22 \%$ of the territory is included in the high and very high susceptibility category, being represented by steep slopes (most of them under constructions) and torrential formations. This category is mainly represented by the upper part of the slope of the study area, where we can find deep rotational Pleistocene landslides. On the surface of these deep landslides we can find the newly formed shallow ones. Due to the location of these landslides, we can say that scarp areas with high susceptibility are the most prone to reactivation. $21 \%$ of the area is moderately predisposed to mass-movements; this category is mainly represented by the middle part of the slope, where shallow translational landslides are present. 57\% of the area falls into the low and very low susceptibility category, which is represented by the flat areas of the Somes floodplain. These low values are related to anthropic features like road and building embankments.

Studying the landslide inventory, $56.34 \%$ of the landslide pixels are included in the high and very high category; $34.52 \%$ in the moderate category and $9.12 \%$ are included in the low and very low susceptibility class. These results also prove a high reliability of the model applied on the study area. Thus, we can conclude that the most stable landforms are the terraces of the rivers and the floodplain of the Someș River.

We can observe from the resulted map and from numerous field-trips the fact that in the southern part of the study area there were many abandoned orchards and meadows, near them deforestations were made. Nowadays, these areas gradually become built-up areas, therefore accentuating further mass-movements. Sparsely vegetated areas are more exposed to denudation processes, because the roots of the vegetation have a soil-binding power (Bayes, 2015, Kerekes et al., 2016). Between 2005 and 2008, every single safe zone in terms of landslides was shadowed by built-up areas; therefore, beginning with 2008 the constructions are spreading among the most landslide susceptible areas. In only 10 years, the surface of the built-up areas has increased with $69 \%$ compared to the total built-up area surface in 2005 (Fig. 8). 


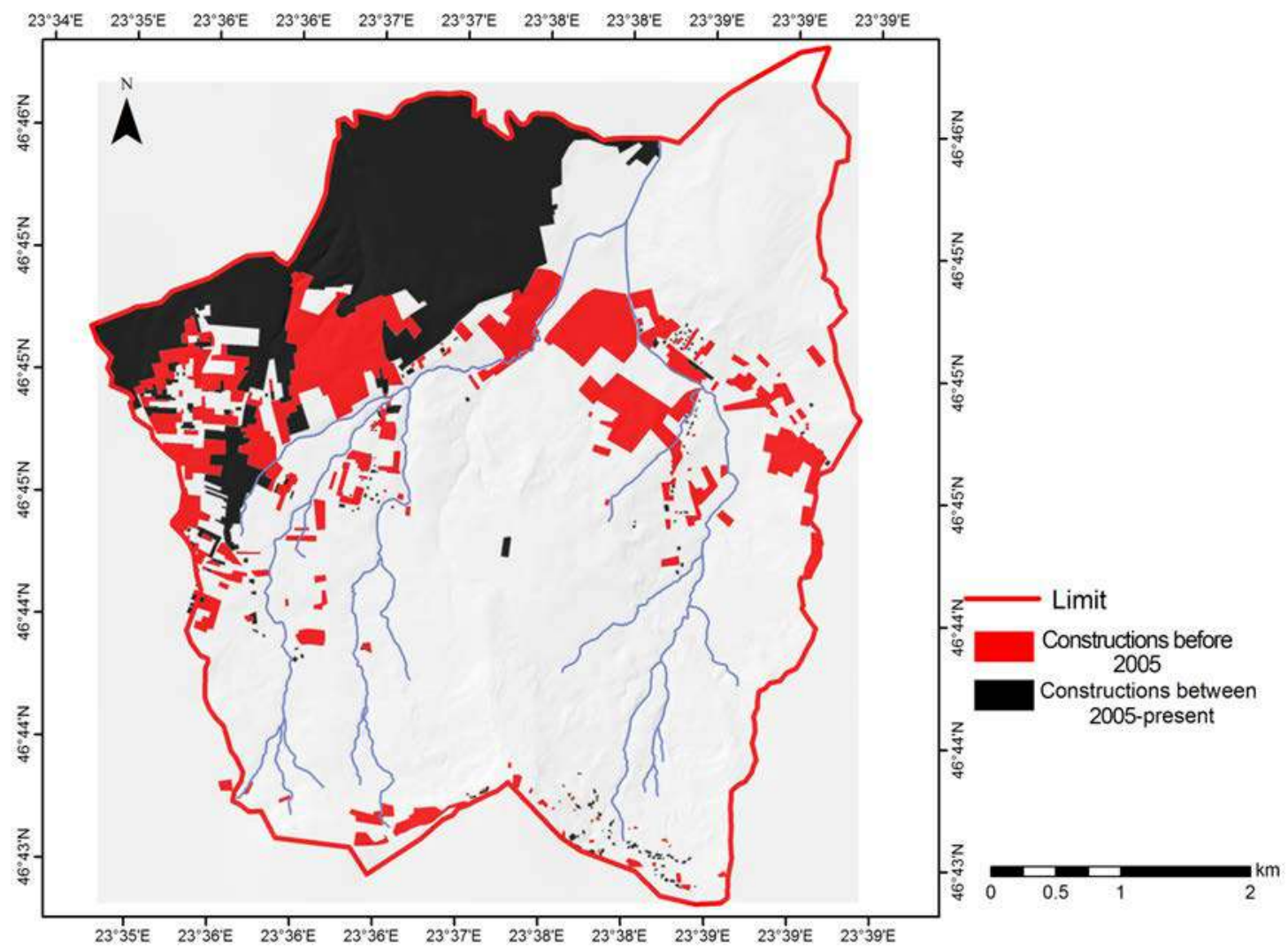

Figure 8 The built-up areas of the investigated area

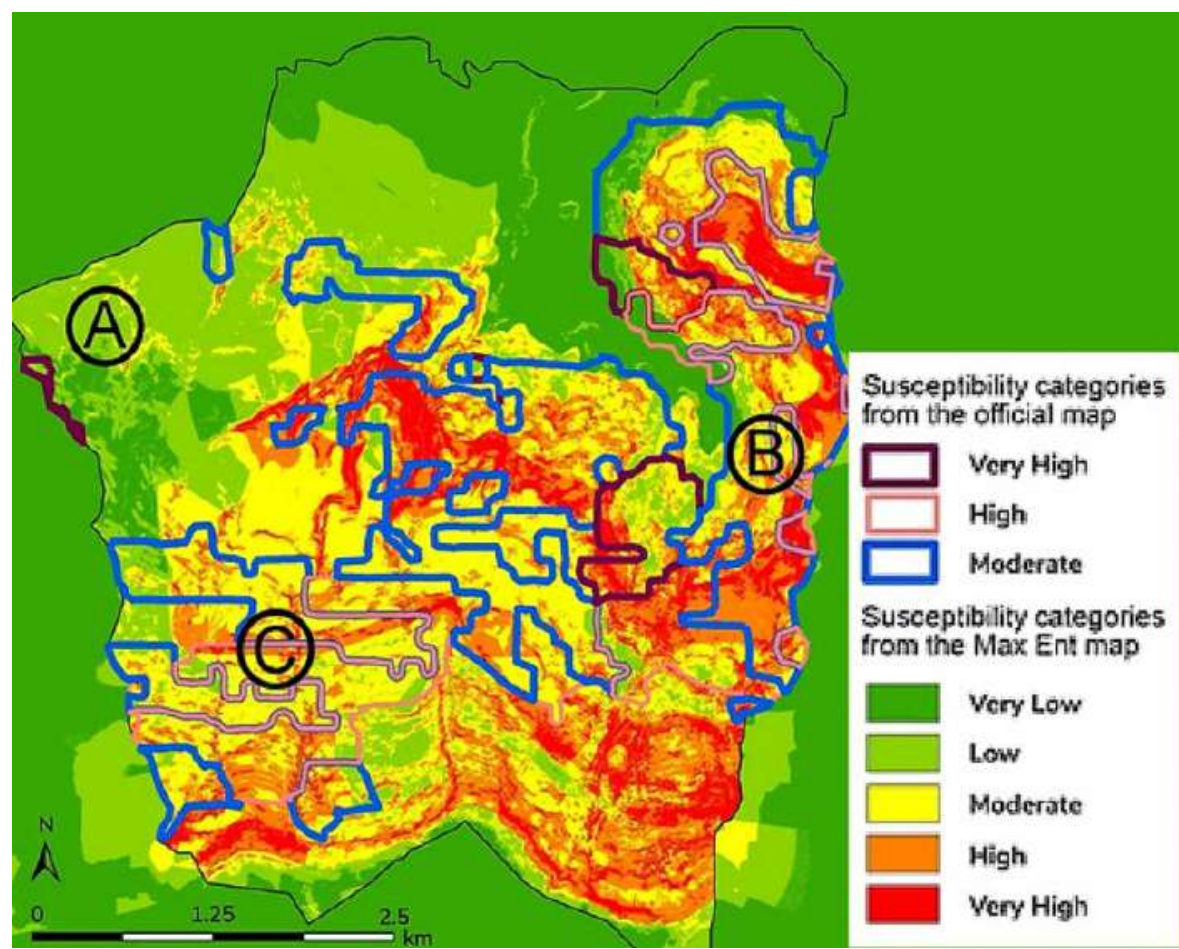

Figure 9 Map displaying the results of confronting the MaxEnt susceptibility map to the official landslide susceptibility map of the study area 

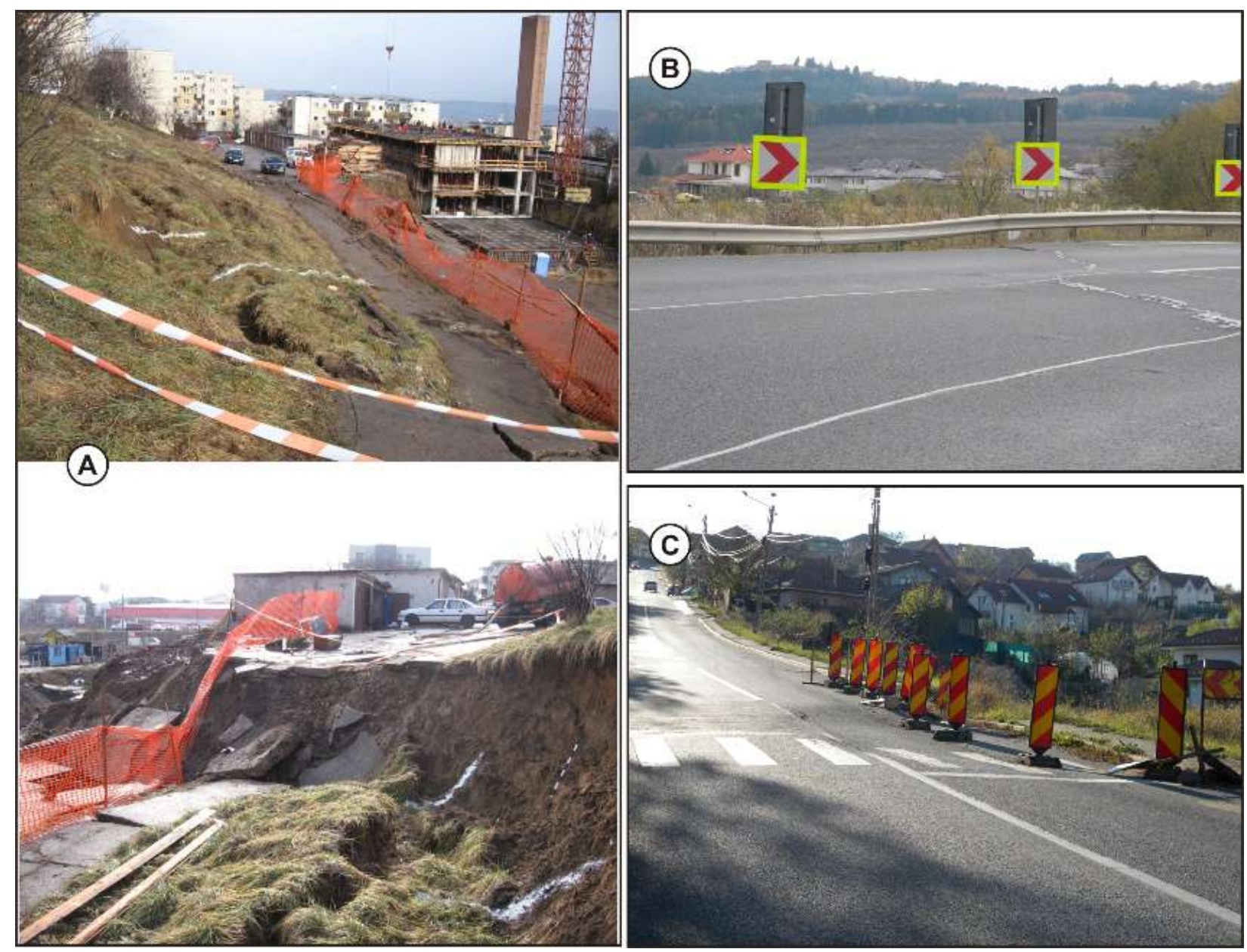

Figure 10 Landslides caused by constructions $(A)$ and affected the roads $(B, C)$

Thus, the main reason why we have chosen this study area is the fact that the extent of the built-up areas is still modest and there are many freely observable areas. Because of the high speed of constructions, the private areas will prevent further studies. Therefore, it becomes necessary to analyse this territory to raise awareness about the existing situation, until it is not too late. The constructions are relatively new, therefore primary mass-movements appear on the roads near the built-up areas (Fig. 9 and Fig.10 A, B, C). The number of constructions implies the increase of the road traffic therefore the trepidation causes landslides (Fig.10 B, C).

In order to calculate the factor contribution, the MaxEnt software used the jackknife technique, which gives the relative contributions of the environmental variables (Park, 2015). This represents the percent of a specific factor being used in the modelling process; therefore these factors have useful information compared to the rest (Kornejady et al., 2017). As a result, we can see in Table 1 the fact that the lithology, slope and human activity have a significant role in landslide occurrence.

Table 1 Percent contribution of the landslide causing factors

\begin{tabular}{cc}
\hline Variable & Percent contribution \\
\hline Lithology & 56.9 \\
Slope Angle & 34.2 \\
Land-use & 7.8 \\
Profile curvature & 0.5 \\
Depth of & 0.3 \\
fragmentation & 0.1 \\
Plan curvature & 0.1 \\
Slope Aspect & \\
\hline
\end{tabular}


Therefore, the results indicate the fact that landslides could be triggered by natural causes like geology and slope angle, as well as human activity (deforestation, constructions).

Comparing our results with the existing official landslide susceptibility map (Fig. 9) we obtained that the susceptibility categories of the official map do not coincide with ours (the official map does not show the low and very low susceptibility levels). We used the overlay method (on a pixel level), and found that, in case of the official map, the most susceptible areas are not properly mapped, therefore a lot of data is missing (we can observe a $21 \%$ matching from the total area between the two maps). Based on the official map, we could calculate the fact that $0.46 \%$ of our landslide inventory is situated in the very high, $1.06 \%$ in the high and $0.6 \%$, in the moderate susceptibility category of the official map. For the rest of the content, there isn't any data available therefore we cannot render a match. Furthermore, we don't know the method which was used to generate the official map, just the results that can be seen. The high degree of the discrepancy is caused by the difference in the resolution of the landslide mapping and susceptibility map generation. We can deduce that the resolution of the official map is approximately $100 \mathrm{~m}$. The map generated by us has $1 \mathrm{~m}$ resolution, thus we could identify more landslides, improving the accuracy of the analysis.

\section{Conclusion}

This study reconfirms that generating a valid landslide susceptibility map is a complex issue: we must put effort in compiling a landslide database as complete and as accurate as possible for the area under investigation; it is necessary to make a complex analysis of the existing statistical models in order to choose the most appropriate to be applied on the study area.

In this study, maximum entropy model was successfully used and tested on the Southern part of the city of Cluj-Napoca (Becaș stream watershed), yielding a high AUC rate (0.844), resulted from the generated ROC curve. We identified (based on longterm observations, many field-trips and studies) seven landslide causing factors: slope, aspect, profile and plan curvature, geology and land-use.

As a result, we obtained the fact that the most prone territories are the steep slopes of the Pleistocene landslides where we can observe intense human activity; $56.34 \%$ of the slides occur on these territories, thus we can conclude that the most severe predisposing factors are the human induced activities. The floodplain of the Somes River and the gentle dip-slopes are characterized by low and very low susceptibility.

Future work will focus on a landslide susceptibility map for the entire Cluj-Napoca municipality because in the recent period, due to anthropic factors, many landslides have been reactivated in other important sectors of the city (Fig. 11) has been destroyed due to thoughtless construction works.

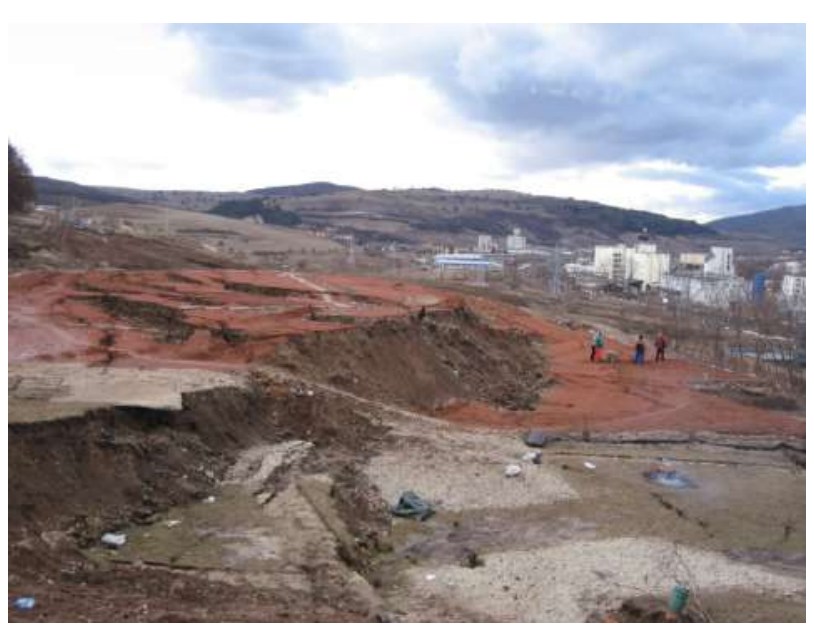

Figure 11 Landslide in a recreational park, 2016

Therefore, prevention of such mass movements becomes possible just with a valid susceptibility map and responsible human activity.

Current jurisdiction specifies that the drillings made by geotechnicians should have just $4 \mathrm{~m}$ depth, therefore these drillings don't reach the base of the slided blocks; few drillings are deeper than 4 $\mathrm{m}$, which is a huge problem, because the Pleistocene mass movements are profound (Tövissiné Losonczi Ibolya, 2004) and many buildings are constructed on them. As an efficient prevention method, geotechnicians should make deeper drillings in order to precisely see the structure, texture, cohesion and composition of the deposits. Also, 
every building foundation should be reinforced with a good amount of steel and concrete. A problem with this method is that it can cause overloading. Nonetheless, people must be informed by local authorities of the existing situation and the risks they are facing.

Future work is needed to improve the resulted map in order to generate future disaster mitigation works and land planning strategies. Further case studies should be performed using a greater number of data sets and landslide causing factors in order to improve the susceptibility map.

\section{References}

Aleotti P, Chowdhury R. 1999. Landslide hazard assessment: summary, review and new perspectives. Bull. Eng Geol Environ, 58: 21-44.

Băcăuanu V. 1980. The Moldavian Plateau. Nature, Man, Society, (in Romanian) Editura Științifică și Enciclopedică, București.

Bajat B, Hengl T, Kilibarda M, Krunic N. 2011. Mapping population change index in Southern Serbia (19612027) as a function of environmental factors. Comput. Environ. Urban. Syst., 35(1): 35-44.

Bayes A. 2015. Landslide susceptibility modelling applying user-defined weighting and data-driven statistical techniques in Cox's Bazar Municipality. Nat Hazards, 79: 1707-1737.

Beguería S. 2006. Validation and evaluation of predictive models in hazard assessment and risk management. Natural Hazards, 37: 315-329.

Blesius L, Weirich F. 2010. Shallow landslide susceptibility mapping using stereo air photos and thematic maps. Cartogr. Geogr. Inf. Sci., 37: 105-118.

Cao B, Bai C, Zhang L, Li G, Mao M. 2016. Modelling landslide distribution of Cornus officinalis with Maxent modeling and fuzzy logics in China. J. Plant Ecol. rtw009.

Chen W, Chai H, Sun X, Wang Q, Ding X, Hong H. 2016. A GIS-based comparative study of frequency ratio, statistical index and weights-of-evidence models in landslide susceptibility mapping. Arabian Journal of Geosciences, 9: 204, https://doi.org/10.1007/s12517015-2150-7.

Conforti M, Robustelli G, Muto F, Critelli S. 2011. Application and validation of bivariate GIS-based landslide susceptibility assessment for the Vitravo river catchement (Calabria, South Italy). Nat. Hazards, DOI 10.1007/s11069-011-9781-0.
Constantinov T, Crivova O, Răileanu V, Nedealcov M. 2009. Application of relief's fragmentation depth estimation method for Codry Plateau Area, Republic of Moldova. East European Journal of Geographical Information Systems and Remote Sensing, 14: 5257.

Dahal RK, Hasegawa S, Nonomura S, Yamanaka M, Masuda T, Nishino K. 2008. GIS-based weights-of-evidence modelling of rainfall-induced landslides in small catchments for landslide susceptibility mapping. Environmental Geology, 54: 311-324.

Dai FC, Lee CF, Li J, Xu ZW. 2001. Assessment of landslide susceptibility on the natural terrain of Lantau Island, Hong Kong. Environ. Geol., 40(3): 381-391.

Davis J, Blesius L. 2015. A hybrid physical and maximumentropy landslide susceptibility model. Entropy, 17: 4271-4292.

Deleo JM. 1993. Receiver operating characteristic laboratory (ROCLAB): software for developing decision strategies that account for uncertainty. In: Proceedings of the Second International Symposium on Uncertainty Modelling and Analysis. College Park, Computer Society Press, pp. 318-325.

Ding Q, Chen W, Hong H. 2016. Application of frequency ratio, weights of evidence and evidential belief function models in landslide susceptibility mapping. Geocarto Int., 6049: 1-21.

Elith J, Phillips SJ, Hastie T, Dudík M, Chee YE, Yates CJ. 2011. A statistical explanation of MaxEnt for ecologists. Divers. Distrib., 17(1): 43-57.

Felicísimo A, Cuartero A, Remondo J, Quiros E. 2013. Mapping landslide susceptibility with logistic regression, multiple adaptive regression splines, classification and regression trees, and maximum entropy methods: a comparative study. Landslides, 9: 175189.

Franklin J. 2009. Mapping Species Distributions, Spatial Inference and Prediction. Cambridge University Press.

Guzzetti F, Carrara A, Cardinali M, Reichenbach P. 1999. Landslide hazard evaluation: a review of current techniques and their application in a multi-scale study, Central Italy. Geomorphology, 31(1-4): 181216.

Halvoresen R. 2012. A gradient analytic perspective on distribution modelling. Sommerfelt, 35: 1-165.

Hamming RW. 1991. Art of Probability. Addison Wesley Publishing Company.

Hungr O, Leroueil S, Picarelli L. 2014. The Varnes classification of landslide types, an update. Landslides, 11: 167-194.

Jaime R, Alcántara JM, Bastida JM, Rey PJ. 2015. Complex patterns of environmental niche evolution in Iberian 
columbines (genus Aquílegia, Ranunculaceae). Plant Ecol., 8(5): 457-467.

Jaynes ET. 1957. Information theory and statistical mechanics. Physical Review, Series II 106(4): 620.

Kavzoglu T, Sahin EK, Colkesen I. 2014. Landslide susceptibility mapping using GIS-based multi-criteria decision analysis, support vector machines and logistic regression. Landslides, 11: 425-439.

Kavzoglu T, Sahin EK, Colkesen I. 2015. An assessment of multivariate and bivariate approaches in landslide susceptibility mapping: a case study of Duzkoy district. Nat hazards, 76: 471-496.

Kerekes A-H, Horváth Cs. 2016. Landslide susceptibility evaluation using GIS. Case study: Silvanie Hills (Romania). Studia UBB Geographia, LXI, (2): 85-99.

Kornejady A, Ownegh M, Bahremand A. 2017. Landslide susceptibility assessment using maximum entropy model with two different data sampling methods. Catena, 152: 144-162.

Kumar R, Anbalagan R. 2015a. Landslide susceptibility zonation in part of Tehri reservoir region using frequency ratio, fuzzy logic and GIS. J. Earth Syst. Sci., 124: 431-448.

Liberatoscioli E, Van Westen C, Soldati M. 2017. Assessment of landslide susceptibility for civil protection purposes by means of GIS and statistical analysis: lessons from the Province of Modena, Italy. Revista de Geomorfologie, 19: 29-43.

Liu Y, Guo Q, Tian Y. 2012. A software framework for classification models of geographical data. Comput. Geosci. 42: 47-56.

Lombardo L, Bachofer F, Cama M, Märker M, Rotigliano E. 2016. Exploiting Maximum Entropy method and ASTER data for assessing debris flow and debris slide susceptibility for the Giampilieri catchment (northeastern Sicily, Italy). Earth Surf. Process. Landforms, DOI: 10.1002/esp.3998.

Luzi L, Pergalani F. 1999. Slope instability in static and dynamic conditions for urban planning, the 'Oltre Po Pavese' case history (Regione Lombardia-Italy). Nat. Hazards, 20(1): 57-82.

Manea Ş, Surdeanu V. 2012. Landslides hazard assessment in the Upper and Middle Sectors of the Strei Valley. Revista de Geomorfologie, 14: 49-55.

Meinhardt M, Fink M, Tünschel H. 2015. Landslide susceptibility analysis in central Vietnam based on an incomplete landslide inventory: Comparison of a new method to calculate weighting factors by means of bivariate statistics. Geomorphology, doi: 10.1016/j.geomorph.2014.12.042.

Montgomery DR. 1994. Road surface drainage, channel initiation, and slope instability. Water Resour. Res., 30: 1925-1932.
Moosavi V, Niazi Y. 2016. Development of hybrid wavelet packet-statistical models (WP-SM) for landslide susceptibility mapping. Landslides, 13(1): 97-114.

Muscarella R, Galante PJ, Soley-Guardia M, Boria RA, Kass JM, Uriarte M, Anderson RP. 2014. ENMeval, an R package for conducting spatially independent evaluations and estimating optimal model complexity for Maxent ecological niche models. Methods Ecol. Evol., 5(11): 1198-1205.

Neaupane KM, Achet SH. 2004. Use of back propagation neural network for landslide monitoring: a case study in the higher Himalaya. Engineering Geology, 74(34): 213-226.

Necula N, Niculiță M. 2017. Landslide reactivation susceptibility modeling in Iași Municipality. Revista de Geomorfologie, 19: 101-117.

Nefeslioglu HA, Gokceoglu C, Sonmez H. 2008. An assessment on the use of logistic regression and artificial neural networks with different sampling strategies for the preparation of landslide susceptibility maps. Engineering Geology, 97: 171-191.

Pandey VK. 2015. Predictive landslide susceptibility assessment using the weight-of-evidence method in north-central Garhwal Himalaya, India. Phys. Geogr., 36: 510-536.

Pandey VK, Pourghasemi HR, Sharma MC. 2018. Landslide susceptibility mapping using maximum entropy and support vector machine models along the Highway Corridor, Garhwal Himalaya. Geocarto International, DOI: 10.1080/10106049.2018.1510038.

Park NW. 2015. Using maximum entropy modelling for landslide susceptibility mapping with multiple geoenvironmental data sets. Environ. Earth Sci., 73(3): 937949.

Pearson RG, Raxworthy CJ, Nakamura M, Townsend Peterson A. 2007. Predicting species distribution from small numbers of occurrence records, a test case using cryptic geckos in Madagascar. J. Biogeogr. 34(1): 102-117.

Petrea D, Bilașco Ș, Roșca S, Fodorean I, Vescan I. 2014. The determination of the landslide occurrence probability by spatial analysis of the Land Morphometric characteristics (case study: the Transylvanian Plateau). Carpath J Environ Sci, 9(2): 91-110.

Phillips SJ, Dudík M, Schapire RE. 2004. A maximum entropy approach to species distribution modelling. Twenty first Int. Conf. Mach. Learn. ICML 04 69, 83, DOI: 10.1145/1015330.1015412.

Phillips JS, Anderson RP, Schapired RE. 2006. Maximum entropy modelling of species geographic distributions. Elsevier Ecological Modelling, 190: 231-260. 
Phillips SJ, Dudík M. 2008. Modelling of species distribution with Maxent: new extensions and a comprehensive evaluation. Ecography, 31: 161-175.

Poszet Sz L. 2017. Studiu de geomorfologie aplicată în zona urbană Cluj-Napoca. Editura Scientia, 180 pp.

Pradhan B, Lee S. 2010. Delineation of landslide hazard areas on Penang Island, Malaysia, by using frequency ratio, logistic regression, and artificial neural network models. Environmental Earth Science, 60: 1037-1054.

Pradhan B, Youssef AM. 2009. Manifestation of remote sensing data and GIS on landslide hazard analysis using spatial-based statistical models. Arabian Journal of Geosciences, 3(3): 319-326.

Pourghasemi HR, Mohammady M, Pradhan B. 2012a. Landslide susceptibility mapping using index of entropy and conditional probability models in GIS: Safarood Basin, Iran. Catena, 97: 71-84.

Pourghasemi HR, Pradhan B, Gokceoglu C. 2012b. Remote sensing data derived parameters and its use in landslide susceptibility assessment using Shannon's Entropy and GIS. Appl. Mech. Mater., 225: 486-491.

Rahmati O, Haghizadeh A, Pourghasemi HR, Noormohamadi F. 2016. Gully erosion susceptibility mapping, the role of GIS-based bivariate statistical models and their comparison. Nat. Hazards, 82: 1231-1258.

Ross SM. 2014. Introduction to probability models. Academic press.

Rossi M, Guzzetti F, Reichenbach P, Mondini AC, Peruccacci S. 2009. Optimal landslide susceptibility zonation based on multiple forecasts. Geomorphology, 114: 129-142.

Schumm SA. 1979. Geomorphic thresholds: the concept and its applications. Trans. Inst. Br. Geogr., 4: 485515.

Shannon CE. 1948. A mathematical theory of communication. Bell Syst. Tech. J., 27: 379-423 and 623-656. Mathematical Reviews (MathSciNet), MR10, $133 \mathrm{e}$.

Sidle RC, Ochiai H. 2006. Processes, prediction, and land use. Water Resources Monograph. American Geophysical Union, p. 312.

Surdeanu V. 1998. The Geography of the degraded lands (in Romanian). Presa Universitară Clujeană, Cluj-Napoca, $274 \mathrm{p}$.

Swets JA. 1988. Measuring the accuracy of diagnostics systems. Science, 240(4857): 1285-1293.

Trigila A, Iadanza C, Esposito C, Scarascia-Mugnozza G. 2015. Comparison of logistic regression and random forests techniques for shallow landslide susceptibility assessment in Giampilieri (NE Sicily, Italy). Geomorphology, 249: 119-136.

Tövissiné Losonczi Ibolya, 2004, Kolozsvár építésföldtani sajátosságairól (About the architectural geology feature of Cluj-Napoca), Földtani Közlemények, 134(4): 589-600, Budapest.

Tufescu V. 1966. Natural relief modelling and accelerated erosion (in Romanian). Editura Academiei RSR, București.

Uchida T, Kosugi K, Mizuyama T. 2001. Effects of pipeflow on hydrological process and its relation to landslide: A review of pipeflow studies in forested headwater catchments. Hydrol. Process, 15: 21512174.

Van Den Eeckhaut M, Reichenbach P, Guzzetti F, Rossi M, Poesen J. 2009. Combined landslide inventory and susceptibility assessment based on different mapping units: an example from the Flemish Ardennes, Belgium. Natural Hazards and Earth System Sciences, 9: 507-521.

Varnes DJ. 1978. Slope movement types and processes. In: Schuster RL, Krizek RJ. (eds.): Landslides: analysis and control; Volume Special Report 176; National Academy of Science Transportation Research Board: Washington, DC, USA, pp. 11-33.

Vorpahl P, Elsenbeer H, Märker M, Schröder B. 2012. How can statistical models help to determine driving factors of landslides? Elsevier Ecological Modelling, 239: 27-39.

Wahyudi AD, Bartzke M, Küster E, Bogaert P. 2012. Maximum entropy estimation of a benzene contaminated plume using ecotoxicological assays. Environ. Pollut., 172(C): 170-179.

Wanek F, Poszet Sz L. 2011. A Kis-Szamos jobb oldali lejtőinek földtani felépítéséből és morfológiájából adódó lejtőveszélyeztetettség Kolozsvár területén (a a Papok-völgye és a Békás-völgye között) - (Landslide susceptibility assessment on the right slope of the Someșul Mic Valley, Cluj-Napoca Study Area <between the Valley of Becaș and Popii Stream>). Kárpát-medencei Környezettudományi Konferencia, VII, Kolozsvár, pp. 687-691.

Yang Z, Qiao J. 2009. Entropy-based hazard degree assessment for typical landslides in the Three Gorges Area, China. Environmental Science and Engineering, 519-529. doi.org/10.1007/978-3-642-00132-1_25.

Yang Z, Qiao J, Zhang X. 2010. Regional landslide zonation based on entropy method in Three Gorges Area, China. Seventh International Conference on Fuzzy Systems and Knowledge Discovery (FSKD 2010), 1336-1339.

Yang XQ, Kushwaha SPS, Saran S, Xu J, Roy PS. 2013. Maxent modelling for predicting the potential distribution of medicinal plant, Justicia adhatoda $L$. in Lesser Himalayan foothills. Ecol. Eng., 51: 83-87.

Yilmaz I. 2009. Computers \& Geosciences Landslide susceptibility mapping using frequency ratio, logistic 
regression, artificial neural networks and their comparison: a case study from Kat landslides (Tokat Turkey). Is. Comput. Geosci., 35: 1125-1138.

Yu J, Wang C, Wan J, Wang Q, Nie S. 2014. A modelbased method to evaluate the ability of nature reserves to protect endangered tree species in the context of climate change. For. Ecol. Manag., 327: 48-54.
Yufeng S, Fengxiang J. 2009. Landslide stability analysis based on generalized information entropy. International Conference on Environmental Science and Information Application Technology, pp. 83-85.

*http://www.primariaclujnapoca.ro/proiectpug.html **https://biodiversityinformatics.amnh.org/open_source/ maxent/ 